\title{
Tracking characterization of Mycobacterium strains in Tanzania and some sub-Saharan African Countries: An overview on genotyping studies, implication and trends in advancing technology
}

\author{
Erasto Mbugi $^{\mathrm{a} *}$, Bugwesa Katale ${ }^{\mathrm{b}, \mathrm{g}}$, Julius Keyyu ${ }^{\mathrm{b}}$, Sharon Kendall ${ }^{\mathrm{h}}$, Anita L Michel ${ }^{\mathrm{c}}$, Hazel M Dockrell ${ }^{\mathrm{d}}$, \\ Mark Rweyemamu ${ }^{\mathrm{e}}$, Paul D van Helden ${ }^{\mathrm{f}}$, Mecky Matee ${ }^{\mathrm{g}}$

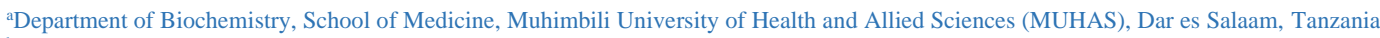 \\ ${ }^{\mathrm{b}}$ Tanzania Wildlife Research Institute (TAWIRI), Arusha, Tanzania \\ ${ }^{\mathrm{c}}$ Centre for Emerging, Endemic and Exotic disease, Royal Veterinary College (RVC), Hawkshead Lane, North Mymms, Hatfield, Hertfordshire, United Kingdom \\ ${ }^{\mathrm{d} F a c u l t y}$ of Infectious and Tropical Diseases, London School of Hygiene and Tropical Medicine (LSHTM), London, United Kingdom \\ ${ }^{\mathrm{e} D S T / N R F}$ Centre of Excellence for Biomedical Tuberculosis Research/MRC, Centre of Molecular and Cellular Biology, Division of Molecular Biology and Human \\ Genetics, Faculty of Health Sciences, University of Stellenbosch, South Africa \\ ${ }^{\mathrm{f} S}$ Southern African Centre for Infectious Disease Surveillance, Sokoine University of Agriculture, Morogoro, Tanzania \\ ${ }^{g}$ Department of Microbiology and Immunology, School of Medicine, Muhimbili University of Health and Allied Sciences (MUHAS), Dar es Salaam, Tanzania \\ hDepartment Molecular Bacteriology, Royal Veterinary College, United Kingdom \\ *Correspondence to Erasto Mbugi (erastombugi@gmail.com)
}

\section{ABSTRACT}

Tuberculosis (TB) is a devastating chronic debilitating infection that imposes a considerable negative impact on human health. The disease also affects the quality of livestock, wildlife and their products. Mycobacterium tuberculosis (M. tuberculosis) is the causative agent for human TB, while Mycobacterium bovis (M. bovis) predominantly causes TB in animals, though is also zoonotic. In Tanzania and other developing countries timely diagnosis of disease is hampered by poor access to appropriate capacity and technology to characterize the pathogen. This review explores the diverse methods available for the diagnosis and characterization of Mycobacterial species and strains isolated from both humans and animals in sub Saharan Africa. The review will identify knowledge gaps and highlight direction for future investigation of the interface TB risk, which could lead to a better regional control strategy. A systematic search of PubMed, Google and Google Scholar retrieved 716 published articles on TB and methods used with the aim of tracking the advancement in technology and to reflect where we are and what can best be done to improve the strategy for best control of the disease. The search terms included but not limited to "(Whole Genome Sequencing AND sub-Saharan Africa); (Diverse TB strains + Human +Animals) AND Tanzania + Africa + Sub-Saharan Africa; (Diverse TB strains + human + animals) OR Tanzania + Africa + Sub-Saharan Africa)'”. The review illustrates an advancement of technology from 1950 s to 2000s with only $17.7 \%$ studies having been done using DNA-based methods and $81.3 \%$ being studies that used conventional methods. Most of the molecular studies cluster in the mid- to late 2000s which could be due to lack of expertise, slow adoption of technology or the high cost of running these valuable molecular tests. This overview on genotyping studies and trend in molecular studies highlights the need for more investment in this region of the world. An increased use of molecular methods will help in increasing the chances of detecting new TB strains in circulation and identifying potential risks for cross-transmission at humans-livestock-wildlife interface. A strengthened ability to detect and characterizes disease will better support country and regional control strategies.

Key words: Mycobacterium strains, Trends, Genotyping studies, Advancing technology, Tanzania.

A Corrigendum has been published for this paper, click here.

\section{INTRODUCTION}

$\mathrm{T}$ uberculosis (TB) is a devastating chronic debilitating infection which negatively impacts on the health and wellbeing of humans, and livestock and wildlife and their products. With potential for cross-transmission of the disease amongst species, an inter-sectoral participatory approach that involve multiple disciplines (One Health 
approach) could be relevant as a control and disease management strategy, particularly in developing countries. Whilst Mycobacterium Tuberculosis is predominantly the causative agent for human TB, Mycobacterium bovis predominantly causes $\mathrm{TB}$ in animals, though is also zoonotic. Zoonotic TB risk factors include consumption of animal products, particularly raw milk and uncooked meat. Transmission of bovine tuberculosis (bTB) by M. bovis from cattle to humans is well known but little is known of transmission of bTB between animals in Africa and risk of transmission to from humans. Many societies in Africa share shelters with animals, particularly cattle and goats. It is therefore important to explore the disease dynamics in these interactions. Understanding the habitual practices, and being able to identify the prevalent TB strains in circulation in subSaharan Africa are important to design suitable interventions to improve health in both humans and animals. In this review, we explore the diversity of Mycobacterial species and strains isolated from both humans and animals in subSaharan Africa in order to identify knowledge gaps to drive further research and support an evidence based regional control strategy.

TB occurs worldwide with about 10 million cases and 1.6 million deaths in 2017 (WHO). TB is amongst the top causes of deaths in women aged 15 to 44 years $^{1}$ and is even more prevalent in males. According to the World Health Organization (WHO) reports the largest number of new TB cases occurred in Asia, ( $62 \%$ of new cases globally in the last 2 years) and then sub-Saharan African (25\% of all new cases in 2017) ${ }^{2}$. The global impact of TB is exacerbated by co-infection with $\mathrm{HIV}^{8}$ and drug resistance ${ }^{3-10}$. Extensive drug resistant TB (XDR-TB) has been widely reported in many TB endemic countries ${ }^{8,11-17}$. Tanzania is among the African countries with highest burden of TB in the world; having approximately 295 TB cases per 100,000 adults. In addition, Tanzania has a national HIV prevalence of 5\%, which increases risk of TB infection by over 30 times $^{1}$.

Existing economic and social obstacles challenge global TB elimination ${ }^{5}$. Treatment and prevention strategies are hampered by socio-economic problems and limited political will. Such strategies rely on better diagnostics to increase case detection ${ }^{5}$, and to reduce the risks of exposure. The implementation of disease control policies, including case management, require adequate and consistent funding ${ }^{5}$. Part of the strategy should bring in the concept of 'One Health' with medical, veterinary and other stakeholders such as environmentalists which could be a key control strategy ${ }^{18}$.

\section{Animal tuberculosis, zoonotic and epizoonotic implications}

Bovine TB (bTB) in humans is a well-documented zoonosis and is thought to be acquired mainly from cattle through the consumption of infected meat or milk, or via the respiratory route. However, humans can also be a source of infection to livestock, for example there are reports of the isolation of $M$. tuberculosis in goats and sheep in Ethiopia ${ }^{19}$ and even a wild elephants in South Africa ${ }^{20}$. The epizoonotic and zoonotic nature of TB would benefit from a One Health approach to control. For example, the use of genotyping and whole genome sequencing methods, can help to identify sources and transmission routes within and across species and geographic regions ${ }^{21}$, which may identify points for intervention. These advances in technology, however, need committed and coordinated efforts from both within and outside the health sector $^{22}$. In addition, it will require willingness from governments in endemic areas to invest in TB disease control programs ${ }^{18}$ and not entirely depend on donor-funded programs.

There is insufficient information on the distribution, epidemiology patterns and zoonotic potential of bTB in all environments, but perhaps most pertinently in traditional rural environments ${ }^{23}$. Putting in place diagnostic programs focusing on isolation, culture and pattern discrimination of mycobacteria from human and animal TB cases is important for pinpointing the mechanisms and routes of disease transmission, spread and zoonotic impact. Undiagnosed cases contribute towards the force of infection and disease recurrence ${ }^{24}$. This is particularly so in resource-poor countries (mostly disease endemic African countries) where rare resource sharing could be critically important. In such resource sharing fashion, mycobacterial culture as well as isolation facilities could be done at reduced cost, consequently, enhancing effective and efficient diagnosis ${ }^{23}$. However, diagnosis is only the first step towards control and unfortunately, the test and slaughter strategy for TB positive animals as a control measure is rarely used in African countries, for a variety of reasons including cultural backlash and the lack of funds for adequate compensation. Thus, without change, developing countries (and particularly African countries) will remain focal points for a number of infections in both humans and animals, adversely affecting their economy. The eradication of TB will not be possible without good cooperation and collaboration between medical and veterinary personnel for effective and costefficient investigation, prevention, control and management of the disease ${ }^{23}$. This is well supported by the East African Community which has so far conducted a series of curriculum validation meetings to advocate regional pandemic preparedness with a 'One Health' approach. This is an important step because, although it targets pandemics other than TB, it builds the capacity of practitioners for the development of a common approach for the control of zoonotic infections. A missing link previously identified by Mbugi et $\mathrm{al}^{25}$. 
The epidemiology of tuberculosis has been extensively studied for decades, and considerable technological advancements have increased our ability to explore the disease and its causative agent. In more recent times pathogens such as $M$. tuberculosis and other bacteria have been characterized using their nucleic acids (DNA and RNA) and proteins to study factors such as lineage or strain diversity, drug resistance as well as other physico-chemical properties important for pathogen survival in the host. These methods have provided a particularly suitable tool to investigate the epidemiology of bacterial diseases, including sub-Saharan Africa ${ }^{26}$. Several molecular tools, including polymerase chain reaction (PCR), restriction fragment length polymorphisms (RFLP) analysis, spacer oligonucleotide typing (spoligotyping), mycobacterium interspaced repetitive units variable number tandem repeats (MIRU-VNTR) and sequencing have gradually been adopted in many countries to study the epidemiology of tuberculosis. The advantage of these molecular methods in tuberculosis studies rests on their ability to not only discriminate between isolates and identify strains but also to distinguish antibiotic sensitive from resistant strains in $M$. tuberculosis complex infection. These methods have been used successfully to identify chains of transmission and to trace the origins of infection (or pathogen) ${ }^{27,28}$.

Although various genotyping tools have been instrumental in advancing our understanding of TB dynamics, it is becoming clear that whole genome sequencing is superior to conventional genotyping for $M$. tuberculosis studies, particularly to provide a better understanding of $M$. tuberculosis genome evolution over time in its natural host context. Thus evaluation of the trend of advancement in using these new and modern technologies over time is necessary to get a clear picture on stage of our diagnostic capacity. Diagnostic approaches range from conventional genotyping to sequencing, allowing for diverse species and strains of M. tuberculosis complex (MTBC) to be discerned. This approach has been useful in tracing the evolution of strains over time ${ }^{29}$, the geospatial distribution of strains ${ }^{30}$ as well as the strains of $M$. tuberculosis that seem to be independently acquiring drug resistance ${ }^{31,32}$. Proper diagnosis is important, since complimentary studies on nontuberculous mycobacteria (NTM) have shown the potential of diverse NTM species for causing disease in both animals and humans ${ }^{33}$. Despite the availability of these genotyping methods, very few studies tracing TB strains in human and animals in sub-Saharan Africa have been conducted.

\section{Literature Search Strategy}

A literature search was conducted using PubMed with search teams "Whole Genome Sequencing AND sub-Saharan Africa". To ensure that the retrieved articles are relevant, PRISM guidelines (http://www.prisma-statement.org/) were used, and the search included sufficient terms to extract maximum number of informative publications.

The search, initially included only studies done in Tanzania, then some sub-Saharan Africa. The initial search retrieved 40 published article (Table 1), three ${ }^{34-36}$ done in Tanzania and the rest (37 articles) done in other areas. Most of these articles were from South Africa and Ethiopia with little coming from Djibouti (1), Mali (1), Nigeria (1), Equatorial Guinea (1), Malawi (1) and Uganda (1). The value of whole genome sequencing has been important in tracking evolutional changes in mycobacterial genome that gradually resulted into development of TB drug resistance.

\section{RESULTS AND DISCUSSION}

\section{Search results and implication}

A total of 716 publications from search were eligible for inclusion in this review $442(61.7 \%)$ of which, originated from Tanzanian studies and 274 (30.3\%) publications originated from other countries (Table 2). The geographic spread of these latter publications were variably and regionally distributed along South Africa, the Horn of Africa, West Africa, East and Central African countries. In the general research results, both conventional and molecular studies were unevenly distributed. The uneven distribution of these studies is a reflection of country and regional variability in adoption of modern technology in disease screening and diagnosis.

In Tanzania there were just 16 studies from 2001 to 2018 which have characterized TB in both humans and animals to genetic level (Table 1). All of those studies used genotyping methods, of which 6 focused on characterization of the infective bacteria (M. bovis) in cattle ${ }^{37-41}$ and rodents ${ }^{42}$, only nine ${ }^{34,35,43-50}$ dealt with infection in humans while the rest were mainly studies that involved conventional methods both in humans and animals. The 16 genetic studies include those carried out at human-animal interface. One study (Katale et al) ${ }^{33}$ explored species diversity of non-tuberculous mycobacteria isolated from humans, livestock and wildlife at their interface.

In Tanzania between 2014 and 2018, there was a gradual increase of genotyping studies resulting in 66 publications (retrieved from PubMed). Similarly, 15 publications have been published that use the rapid GeneXpert test (Cepheid, USA), a molecular test for TB detecting the presence of TB bacteria, as well as testing for rifampicin resistance (Table 2 ). Despite the approximately 4-fold increase in genetic based studies over the previous 4 years compared to those prior to 2014 , only four $(4 / 66,6.1 \%)$ of the studies $33,39,48,49$, have focused on the animal-human interface in tuberculosis. The rest focused on human TB alone or animal TB alone or were simply diagnostic, leaving a large gap in our 
understanding of the dynamics of tuberculosis at the interface.

Genotyping and phylogeographical analyses done in Tanzania have highlighted the predominance of the CAS, T, EAI, and LAM MTBC lineages in Tanzania with the most frequent Spoligotype International Types (SITs) being SIT21/CAS1-Kili, SIT59/LAM11-ZWE and SIT126/EAI5. Other circulating lineages include Haalem, Beijing, LAM, S, $\mathrm{T}$, and $\mathrm{X}$ and Manu. Studies done in the past four years while mapping the MTBC genetic diversity in Tanzania, neighbouring East African and other several African countries ${ }^{49}$, have described a new lineage (designated EAI3TZA) that seems to be specific to Tanzania ${ }^{48,49}$. The studies collectively highlighted the absence of clear evidence for recent cross-species transmission of either $M$. tuberculosis or $M$. bovis between humans, livestock and wild animals ${ }^{33,39,48,49}$ as well as identifying a novel $M$. bovis strain which have not been previously reported in the Serengeti ecosystem ${ }^{48}$. This information is important when evaluating prevailing strains in an area where humans and animals are in intense contact with potential for cross-transmission.

Those studies focusing exclusively on animal to animal transmission have also highlighted that, despite wild animals being at risk of acquiring $M$. bovis infection from livestock due to occasional interactions in sharing of pasture and water sources, no M. bovis was isolated from hunted wild animals. It should be noted that such studies may have been biased to low endemic areas and have not sampled large numbers of animals, nor targeted animals that were visibly unhealthy and therefore the presence of $M$. bovis cannot be ruled out and this does not rule out a call for integrated efforts by all stakeholders for effective control of spread of tuberculosis ${ }^{41}$.
In Uganda both M. tuberculosis and M. bovis have been studied in humans and animals. Characterization of modern M. tuberculosis strains has indicated spoligotypes and drug susceptibility patterns of isolates from tuberculosis patients to consist of strains mainly belonging to the Uganda genotype and with a low anti-TB drug resistance rate ${ }^{51}$. A wide diversity of strains had previously been reported ${ }^{52}$ with the majority of the TB cases supposedly due to reactivation rather than re-infection. Studies have also shown that despite TB epidemic genotypes being predominantly localized ${ }^{53,54}$, strain types were not associated with drug resistance nor HIV sero-status ${ }^{53}$. Despite having little impact on the clinical course for individual patients, infection with multiple MTBC strains has been shown to occur in patients with a first episode of pulmonary disease, in settings with high TB incidence ${ }^{55}$.

Characterization of $M$. bovis isolates in Uganda have indicated some spoligotype patterns that had not been previously reported ${ }^{56}$, indicating the lack of comprehensive studies in this country. It was reported that infected carcasses, even with multiple sites of infection, are not routinely condemned as unfit for human consumption, and even if this should be done, people may illegally obtain meat from the carcasses for consumption, particularly in rural areas ${ }^{56}$. This situation occurs in most of the traditional African communities and societies where cattle are kept for prestige rather than as a source of wealth and food. This cultural difference between so-called developed and developing countries necessitates the need for specific and relevant approaches in control strategies ${ }^{57}$.

TABLE 1. Published Tuberculosis research in humans and animals performed in Tanzania from the year 2000 to $2018 *$.

\begin{tabular}{|c|c|c|c|c|}
\hline Infection category & Target host & Method & Year & Author \\
\hline Bovine tuberculosis & Cattle & Tuberculin test & 2001 & Kazwala et al ${ }^{63}$ \\
\hline M. bovis infection & humans & Culture and biochemical typing & 2001 & Kazwala et al ${ }^{64}$ \\
\hline $\begin{array}{l}\text { Diseases of humans and } \\
\text { their domestic mammals }\end{array}$ & $\begin{array}{l}\text { Humans } \\
\text { domestic } \\
\text { mammals }\end{array}$ & Species database construction & 2001 & Cleaveland et al ${ }^{67}$ \\
\hline $\begin{array}{l}\text { M. tuberculosis and } M . \\
\text { bovis }\end{array}$ & humans & Interview & $2003 \mathrm{a}$ & Mfinanga et al ${ }^{68}$ \\
\hline $\begin{array}{l}\text { M. tuberculosis and } M . \\
\text { bovis }\end{array}$ & humans & Interview & $2003 b$ & Mfinanga et al ${ }^{69}$ \\
\hline $\begin{array}{l}\text { Bovine tuberculosis and } \\
\text { non-specific infections }\end{array}$ & Cattle & Tuberculin test & 2003 & Shirima et al ${ }^{65}$ \\
\hline $\begin{array}{l}\text { M. tuberculosis, M. bovis, } \\
\text { non-tuberculous } \\
\text { mycobacterium and HIV }\end{array}$ & Humans & Culture and comparison of isolates & 2004 & Mfinanga et al 70 \\
\hline Bovine tuberculosis & Wildlife & Enzyme Immunoassay & 2005 & Cleaveland et al ${ }^{66}$ \\
\hline
\end{tabular}




\begin{tabular}{|c|c|c|c|c|}
\hline M. bovis & Cattle & PCR, RFLP and spoligotyping & 2006 & Kazwala et al ${ }^{45}$ \\
\hline M. tuberculosis & Humans & Spoligotyping & 2006 & Eldholm et al ${ }^{48}$ \\
\hline Human tuberculosis & Humans & Culture & 2007 & Søborg et al 71 \\
\hline $\begin{array}{l}\text { M. tuberculosis in HIV } \\
\text { infection }\end{array}$ & Humans & Spoligotyping & 2007 & Kibiki et al ${ }^{51}$ \\
\hline Human tuberculosis & Human & $\begin{array}{l}\text { Microscopy, culture, drug } \\
\text { susceptibility testing, Chest X-ray } \\
\text { and CD4+T cells count (blood) }\end{array}$ & 2008 & Ngowi et al 72 \\
\hline Common zoonoses & Humans & Structured questionnaire & 2008 & John et al ${ }^{73}$ \\
\hline $\begin{array}{l}\text { Bovine tuberculosis and } \\
\text { atypical mycobacterioses }\end{array}$ & Cattle & $\begin{array}{l}\text { Tuberculin test, milk culture, RNA } \\
\text { sequencing and PCR }\end{array}$ & 2009 & Durnez et al ${ }^{43}$ \\
\hline Various zoonoses & $\begin{array}{l}\text { Human, animal } \\
\text { and environment }\end{array}$ & Review & 2009 & Mazet et al ${ }^{74}$ \\
\hline TB infection & Humans & $\begin{array}{l}\text { TB detection using rats from sputum } \\
\text { samples }\end{array}$ & 2009 & Weetjens et al ${ }^{75}$ \\
\hline TB infection & Humans & $\begin{array}{l}\text { TB detection using rats from sputum } \\
\text { samples }\end{array}$ & 2010 & Poling et al 76 \\
\hline tuberculosis & Cattle & $\begin{array}{l}\text { Spoligotyping, VNTR typing, } \\
\text { microarray analysis, deletion typing } \\
\text { and IS6110 RFLP typing }\end{array}$ & 2011 & Berg et $\mathrm{al}^{\# ~} 42$ \\
\hline Non-specific mycobacteria & $\begin{array}{l}\text { Small mammals } \\
\text { (rodents) }\end{array}$ & Culture of isolates and PCR & 2011 & Durnez et al ${ }^{47}$ \\
\hline Bovine tuberculosis & Cattle and wildlife & Deletion typing and spoligotyping & 2013 & Mwakapuja et al 46 \\
\hline TB infection & Humnas & $\begin{array}{l}\text { M. tuberculosis DNA sequencing for } \\
\text { resistance mutations in rpoB }\end{array}$ & 2013 & Mpagama et al 77 \\
\hline $\begin{array}{l}\text { Non-tuberculous } \\
\text { mycobacteria }\end{array}$ & $\begin{array}{l}\text { Cattle-human } \\
\text { interface }\end{array}$ & Culture, PCR and sequencing & 2014 & Katale et al ${ }^{41}$ \\
\hline $\begin{array}{l}\mathrm{TB} \text { infection and drug } \\
\text { resistance }\end{array}$ & Humans & Culture, PCR, spoligotyping & 2014 & Kidenya et al ${ }^{78}$ \\
\hline TB infection & $\begin{array}{l}\text { Humans-animal } \\
\text { interface }\end{array}$ & $\begin{array}{l}\text { Culture, PCR, spoligotyping, MIRU- } \\
\text { VNTR }\end{array}$ & 2015 & Mbugi et al 53 \\
\hline Bovine tuberculosis & $\begin{array}{l}\text { Human-animal } \\
\text { interface }\end{array}$ & $\begin{array}{l}\text { Culture, PCR, spoligotyping, MIRU- } \\
\text { VNTR }\end{array}$ & 2015 & Katale et al ${ }^{44}$ \\
\hline $\begin{array}{l}\text { Disseminated TB in HIV- } \\
\text { infected patients }\end{array}$ & Humans & GeneXpert & 2015 & Gamell et al 79 \\
\hline TB infection & Humans & $\begin{array}{l}\text { Microarrays-based } \quad \text { spoligotyping, } \\
\text { MIRU-VNTR }\end{array}$ & 2016 & Hoza et al 49 \\
\hline TB infection & $\begin{array}{l}\text { Human-animal } \\
\text { interface }\end{array}$ & $\begin{array}{l}\text { Spoligotyping and molecular data } \\
\text { mining }\end{array}$ & 2016 & Mbugi et al ${ }^{54}$ \\
\hline TB infection & Humans & GenoType® & 2016 & Hoza AS et al 50 \\
\hline Tuberculous spondylitis & Humans & GeneXpert MTB/RIF & 2016 & Sikalengo et al ${ }^{80}$ \\
\hline TB infection & Humans & GeneXpert MTB/RIF & 2017 & Sariko et al ${ }^{81}$ \\
\hline TB infection & Humans & GeneXpert $®$ & 2017 & Mnyambwa et al 82 \\
\hline TB infection & Humans & $\begin{array}{l}\text { GeneXpert (MTB/RIF) assay and } \\
\text { culture on the Lowenstein Jensen } \\
(\mathrm{LJ}) \text { media }\end{array}$ & 2017 & Kidenya et al ${ }^{52}$ \\
\hline TB infection & Humans & Xpert MTB/RIF assay & 2017 & Mbelele et al $2017^{83}$ \\
\hline TB infection & Humans & GeneXpert GxAlert platform & 2018 & Mnyambwa et al 84 \\
\hline TB infection & Humans & $\begin{array}{l}\text { Fluorescent smear microscopy, } \\
\text { GeneXpert MTB/RIF and } \\
\text { Löwenstein-Jensen (LJ) culture }\end{array}$ & 2018 & Beyanga et al ${ }^{85}$ \\
\hline TB/HIV Co-infection & Humans & $\begin{array}{l}\text { GeneXpert@ MTB/RIF assay and the } \\
\text { MPT64 test }\end{array}$ & 2018 & Jørstad et al ${ }^{86}$ \\
\hline TB infection & Humans & Culture, spoligotyping and WGS & 2018 & Kidenya et al ${ }^{4}$ \\
\hline
\end{tabular}




\begin{tabular}{|c|c|c|c|}
\hline TB Infection & Humans & $\begin{array}{l}\text { Whole genome shotgun sequencing } 2018 \\
\text { and comparative microbial genomic } \\
\text { analyses }\end{array}$ & Mnyambwa et al ${ }^{87}$ \\
\hline
\end{tabular}

Disease dynamics and risk of resurgence

Major factors potentiating TB resurgence include poverty, consequently poor health facilities, which lead to failures in the treatment systems as well as immigration ${ }^{80}$. In addition, a more recent risk is co-morbidity with HIV infection, which increases risk of progression to active disease and latent TB reactivation ${ }^{81-83}$. There is also an alarming rise in drug resistant TB cases. In most localities, it is not known whether the drug resistant cases result from treatment failures, i.e. acquisition, or are from transmission. Genotyping and sequencing studies are ideal tools to establish the major driver of these epidemics and are crucial for design of appropriate intervention and treatment ${ }^{84-89}$. However, this is only possible where there is adequate funding and health care facilities. Therefore, studies using advanced tools have been sporadic and limited in scope while their implementation for routine screening has been impossible in most countries. For example only three published studies ${ }^{35,36,47}$ investigated $M$. tuberculosis at the whole genome sequencing level in Tanzania, while another one (Katale et al, Bacterial Zoonozes Community of Practice under SACIDS, Katale, personal communication) has been done but is not yet published. However, evidence suggests regional TB epidemics in Africa, characterized by genetically distinct lineages of $M$. tuberculosis. M. tuberculosis in these regions may have been introduced from either Europe or Asia and has spread through pastoralism, mining and $\operatorname{war}^{30}$.

Emergence of migrating, highly virulent strains of $M$. tuberculosis, sometimes in association with multidrug resistance, is a warning sign of a serious threat to TB control $^{90}$. This necessitates the identification of major driving forces for the transmission dynamics within specific populations, which in turn may have significant impact on disease control and vaccine development strategies ${ }^{30,91}$. Such goal cannot be achieved without use of advanced molecular methods for screening, diagnosis and comparative molecular epidemiological studies. Advancement in genotyping methods for examples, can provide sufficient information that can determine the approach for planning control strategies. In African settings where there is close interaction and intense contact between humans and animals (including wild animals), the risk of possible crosstransmission of antibiotic resistant TB strains between species is high. This may be an emerging problem, as suggested by the increasing isolation of $M$. tuberculosis from animals, including pigs $^{92}$. In such circumstances, the increase in cross-transmission would consequently mean cross-transmission of resistant TB (M. bovis or $M$. tuberculosis) strains, identification of which, needs advanced diagnostic tools. Improved diagnostic facilities as well as the use of isoniazid prophylactic therapy in endemic areas 5 may be the best global TB control strategy particularly in this era where the focus can as well be on better management of HIV and TB co-infections. All these require early screening and diagnosis at point of care, which can be ensued via advancement in technology.

\section{TB strain diversity in animals}

A variety of molecular methods ranging from simple techniques (Polymerase Chain Reaction, PCR) to Next Generation Sequencing, have variably been adopted to characterize TB strains in diverse clonal complexes both in humans and animals. Similar to TB strain distribution in humans, studies carried in bTB, have found a degree of regional and geographic distribution. While a clonal complex of M. bovis (Af2) was isolated at high frequency from cattle in Uganda, Burundi, Tanzania, and Ethiopia and was identified as an East African strain ${ }^{37}$, another clonal complex (Af1) has been found to be a predominantly West African strain ${ }^{93}$ with high frequencies of isolation from Mali, Nigeria, Cameroon, and Chad. Similar to clonal complexes that have been identified and destined in different regional foci in Africa are the European M. bovis clone complexes $\mathrm{Eu} 1^{21}$ and $\mathrm{Eu} 2^{94}$ which, within Europe, are of high frequency in certain countries and low in others, but have also been identified in Africa, most likely imported with cattle originating from Europe. Within the clonal complexes, there are specific families and strains ${ }^{95}$, allowing further discrimination and which will allow contact tracing, infection route identification and design of interventions. All these groupings of TB strains and their distribution countrywide and regionally, has been made possible via advancement in molecular-based mycobacterial studies.

\section{Contribution of MOTT in TB infection}

Mycobacteria other than M. tuberculosis (MOTT), commonly known as NTMs (non-tuberculous mycobacteria), are mostly ubiquitous environmental mycobacteria found in soil, water, dust as well as in food ${ }^{96-}$ ${ }^{99}$. They do not usually cause infection or illness in healthy 
animals or humans, however many can cause life threatening illness under situations when the immune response becomes weakened, for example ${ }^{100-102}$. Included in this group are Mycobacterium avium complex (MAC), Mycobacterium intracellulare, Mycobacterium kansasii, Mycobacterium marinum, Mycobacterium ulcerans which all habitually cause opportunistic infections. People with critically compromised immune response such as those with HIV/AIDS or chronic lung diseases are very vulnerable to infection by these organisms and symptomatically the disease manifests similarly to TB infection (primarily in lungs, disseminating to other body tissues), however antibiotic susceptibility is often quite different from $M$ tuberculosis ${ }^{103,104}$. As a result, these opportunistic infections may often be confused with TB infection. As such, these mycobacteria have also been referred to as atypical mycobacteria to differentiate them from the typical mycobacterium causing tuberculosis. Contradicting views are available on the spread of atypical mycobacteria in man. Despite atypical mycobacteria living on human skin or in the nose, there is no or little evidence of the mechanism of dissemination. Reports propose the idea of atypical mycobacterial infections as being not spread from person to person but through direct contact with the bacteria in the environment $^{111}$ including drinking water ${ }^{105}$. Direct transmission from animals to humans has again been questioned and considered unimportant for human infection ${ }^{106}$ and infected patients are not necessarily isolated as a protective measure to limit human to human transmission $^{103}$. Regardless of their mode of transmission, the impact of MOTT should receive more attention. At present there are no reliable clinical predictors for the identification of MOTT infection that have been identified for adults and in children, or animals ${ }^{107}$. Furthermore, identification of MOTT infection in resource-limited countries is sorely lacking ${ }^{98}$. A recent study in South Africa ${ }^{108}$ has revealed the diversity of NTM species in cattle and African buffaloes ascribed to at least eight clusters, with a possible eight different NTM species. This report is particularly important as it suggests that inclusion of NTM in investigative and control strategies incorporated in various TB control programs could be important. In so doing any chances of spread of infection both in humans and animals might, to a greater extent, be minimized. The presence of NTM species in all likelihood negatively affects the host immune response to tuberculosis and thus progression to $\mathrm{TB}$ disease and will possibly complicate immune based diagnostics ${ }^{108}$.

Trends in Molecular based Mycobacterial studies

We found published work on tuberculosis in Africa ranging from 7 articles in the 1950s to 600 publications in the 2000s as retrieved from PubMed which is over 80 folds higher in the 2000s than in the 1950s (Search strategy: (Diverse TB strains + Human +Animals) AND Tanzania + Africa + SubSaharan Africa; (Diverse TB strains + human + animals) OR Tanzania + Africa + Sub-Saharan Africa). The search was also complemented by Google and Google Scholar search to widen the chance of capturing more articles. Microsoft Excel sheet was used to add up the number of articles in each category and for calculating proportions where needed to. Where specific tests were needed, we included in the search term e.g. DNA sequencing, GeneXpert accordingly. A total of 716 articles (Table 2) were obtained and manually categorized by EVM into different categories namely molecular, GeneXpert or others (all other approaches than molecular-based). The contribution of published molecular work in TB to the general research work is $17.7 \%$ of the total retrieved published work from 1950-2018. Among these, $15.1 \%$ are typical genotyping emanating publications and about 2.6\% from GeneXpert (Table 2). In the Table we also note that the move from conventional to genotyping molecular methods has been increasing with time with larger proportions of molecular work clustering in the years 2000 -2009 . The trend however is not uniform which could be a reflection of donor dependence for funding such projects and thus periodicity. Too much dependence on donors may have a detrimental effect (boom and bust cycles) and since donors may not prioritize on developing country problems, instead being rather biased to donor priorities. Abuzeid ${ }^{109}$ highlights problems with foreign aid flows from developed to developing countries. This paper further emphasizes the need for examination of such aids for potential detrimental effects, instead of providing solutions to poverty as envisaged. The study also uncovers that most of GeneXpertbased studies falls in the years 2010 onwards, an indication that the technique is relatively new in terms of implementation in Africa.

Table 2: Track record of published work in TB done in Tanzania and other sub-Saharan countries indicating the contribution of molecular methods approach in general research profile.

\begin{tabular}{rrrrrrrr}
\hline SN & $\begin{array}{l}\text { No. of } \\
\text { Manuscripts }\end{array}$ & $\begin{array}{l}\text { Year of } \\
\text { publication }\end{array}$ & Molecular & $\begin{array}{l}\text { Xpert } \\
\text { MTB/RIF }\end{array}$ & $\begin{array}{l}\text { Other } \\
\text { areas }\end{array}$ & Tanzania & Others \\
\hline 1 & 39 & 2018 & 11 & 3 & 25 & 20 & 19 \\
2 & 79 & 2017 & 21 & 5 & 53 & 42 & 37 \\
3 & 50 & 2016 & 13 & 3 & 34 & 22 & 28 \\
4 & 71 & 2015 & 12 & 2 & 57 & 25 & 46 \\
\hline
\end{tabular}




\begin{tabular}{|c|c|c|c|c|c|c|c|}
\hline 5 & 56 & 2014 & 9 & 2 & 45 & 38 & 18 \\
\hline 6 & 46 & 2013 & 5 & 2 & 39 & 34 & 12 \\
\hline 7 & 53 & 2012 & 5 & 1 & 47 & 42 & 11 \\
\hline 8 & 33 & 2011 & 1 & 1 & 31 & 24 & 9 \\
\hline 9 & 32 & 2010 & 4 & 0 & 28 & 24 & 8 \\
\hline 10 & 26 & 2009 & 6 & 0 & 20 & 14 & 12 \\
\hline 11 & 22 & 2008 & 2 & 0 & 20 & 16 & 6 \\
\hline 12 & 22 & 2007 & 4 & 0 & 18 & 19 & 3 \\
\hline 13 & 19 & 2006 & 3 & 0 & 16 & 12 & 7 \\
\hline 14 & 11 & 2005 & 1 & 0 & 10 & 7 & 4 \\
\hline 15 & 6 & 2004 & 1 & 0 & 5 & 5 & 1 \\
\hline 16 & 11 & 2003 & 1 & 0 & 10 & 7 & 4 \\
\hline 17 & 4 & 2002 & 1 & 0 & 3 & 1 & 3 \\
\hline 18 & 11 & 2001 & 0 & 0 & 11 & 9 & 2 \\
\hline 19 & 9 & 2000 & 3 & 0 & 6 & 5 & 4 \\
\hline 20 & 7 & 1999 & 0 & 0 & 7 & 3 & 4 \\
\hline 21 & 5 & 1998 & 1 & 0 & 4 & 3 & 2 \\
\hline 22 & 6 & 1997 & 0 & 0 & 6 & 4 & 2 \\
\hline 23 & 10 & 1996 & 1 & 0 & 9 & 8 & 2 \\
\hline 24 & 18 & 1995 & 1 & 0 & 17 & 12 & 6 \\
\hline 25 & 12 & 1994 & 2 & 0 & 10 & 8 & 4 \\
\hline 26 & 6 & 1993 & 0 & 0 & 6 & 4 & 2 \\
\hline 27 & 3 & 1992 & 0 & 0 & 3 & 3 & 0 \\
\hline 28 & 10 & 1991 & 0 & 0 & 10 & 4 & 6 \\
\hline 29 & 6 & 1990 & 0 & 0 & 6 & 4 & 2 \\
\hline 30 & 2 & 1989 & 0 & 0 & 2 & 2 & 0 \\
\hline 31 & 1 & 1985 & 0 & 0 & 1 & 1 & 0 \\
\hline 32 & 2 & 1984 & 0 & 0 & 2 & 2 & 0 \\
\hline 33 & 1 & 1983 & 0 & 0 & 1 & 1 & 0 \\
\hline 34 & 2 & 1982 & 0 & 0 & 2 & 2 & 0 \\
\hline 35 & 1 & 1978 & 0 & 0 & 1 & 0 & 1 \\
\hline 36 & 1 & 1977 & 0 & 0 & 1 & 1 & 0 \\
\hline 37 & 2 & 1976 & 0 & 0 & 2 & 1 & 1 \\
\hline 38 & 1 & 1975 & 0 & 0 & 1 & 1 & 0 \\
\hline 39 & 1 & 1974 & 0 & 0 & 1 & 1 & 0 \\
\hline 40 & 1 & 1973 & 0 & 0 & 1 & 1 & 0 \\
\hline 41 & 1 & 1972 & 0 & 0 & 1 & 1 & 0 \\
\hline 42 & 3 & 1971 & 0 & 0 & 3 & 1 & 2 \\
\hline 43 & 1 & 1970 & 0 & 0 & 1 & 0 & 1 \\
\hline 44 & 2 & 1968 & 0 & 0 & 2 & 2 & 0 \\
\hline 45 & 1 & 1967 & 0 & 0 & 1 & 0 & 1 \\
\hline 46 & 1 & 1962 & 0 & 0 & 1 & 1 & 0 \\
\hline 47 & 1 & 1961 & 0 & 0 & 1 & 1 & 0 \\
\hline
\end{tabular}




\begin{tabular}{cccccccc}
\hline 48 & 1 & 1960 & 0 & 0 & 1 & 0 & 1 \\
49 & 1 & 1957 & 0 & 0 & 1 & 0 & 1 \\
50 & 1 & 1953 & 0 & 0 & 1 & 0 & 1 \\
51 & 3 & 1952 & 0 & 0 & 3 & 3 & 0 \\
52 & 1 & 1951 & 0 & 0 & 1 & 1 & 0 \\
53 & 1 & 1950 & 0 & 0 & 1 & 0 & 1 \\
\hline Total & $\mathbf{7 1 6}$ & & $\mathbf{1 0 8}$ & $\mathbf{1 9}$ & $\mathbf{5 8 9}$ & $\mathbf{4 4 2}$ & $\mathbf{2 7 4}$ \\
\hline
\end{tabular}

\section{CONCLUSION AND RECOMMENDATIONS}

In Africa, the occurrence of zoonosis is common, in the main part from the close proximity of humans and animals. Exploring the disease dynamics at these interfaces could provide the key for developing successful interventions to improve health in both humans and animals. We now have molecular tools which can examine the transmission dynamics of Mycobacterial disease in these settings. In order to do this, a strategy that involves medical and veterinary professions as well as other stakeholders will be needed. The Southern African Centre for Infectious Disease Surveillance (SACIDS), as well as other consortia working under the One Health concept including CORDS (Coordinating Organizations for Regional Disease Surveillance) may be a good starting point for such an approach. From this review we found an increase in published work in retrievable papers of over 80 -fold in late years compared to earlier years, which is an indicator of trend-wise development in research. Most of molecular studies, however, cluster in the mid- to late 2000s, with little developments since, suggesting a slow adoption of technology and a high cost of running molecular tests. This overview of genotyping studies and trend in molecular studies should therefore provide an insight at regional level for more dedicated efforts to invest in this area. This review lays the foundation for a more robust investigation of TB particularly at human-animal interface to reduce the potential risk of cross-species transmission. This can be achieved by using molecular screening methods to assess the disease dynamics at this interface for early detection to provoke deployment of best control strategies.

\section{Limitations}

Possibility of missing of some papers and reports that were not published is potential limitation that we think might have been the case for our review. However, the 716 published articles in the area we focused are believably, sufficient to reflect the trend in which technological advancement has been growing. We encourage researchers to publish their research work so that can be kept tracked. Our future plans are to further do a systematic review and meta-analysis that could cover the whole of Africa with an improved search strategy.
Acknowledgement: The Southern Centre for Infectious Disease Surveillance (SACIDS) is acknowledged for providing a Postdoctoral Research Fellowship to EM and PhD candidacy for BZK through the Wellcome Trust Grant [WT087546MA] and MUHAS for providing valuable time to accomplish this review.

\section{REFERENCES}

1. WHO, Tuberculosis Fact Sheet No. 104, 2012; http://www.who.int/mediacentre/factsheets/fs104/en/ (2012).

2. T. Sawai, Y. Inoue, S. Doi, K. Izumikawa, H. Ohno, K. Yanagihara, Y. Higashiyama, Y. Miyazaki, Y. Hirakata, T. Tashiro and S. Kohno, "A case of Mycobacterium nonchromogenicum pulmonary infection showing multiple nodular shadows in an immunocompetent patient," Diagn Microbiol Infect Dis, 54 (2006).

3. L. Grandjean, A. Crossa, R.H. Gilman, C. Herrera, C. Bonilla, O. Jave, J.L. Cabrera, L. Martin, A.R. Escombe and D.A.J. Moore, "Tuberculosis in household contacts of multidrug-resistant tuberculosis patients," Int J Tuberc Lung Dis, 15 (2011), 1164-69.

4. L. Grandjean, L. Martin, R.H. Gilman, T. Valencia, B. Herrera, W. Quino, E. Ramos, M. Rivero, R. Montoya, A.R. Escombe, D. Coleman, D. Mitchison and C.A. Evans, "Tuberculosis Diagnosis and Multidrug Resistance Testing by Direct Sputum Culture in Selective Broth without Decontamination or Centrifugation," J Clin Microbiol, 46 (2008), 2339-44.

5. M.S. Jassal and W.R. Bishai, "Epidemiology and Challenges to the Elimination of Global Tuberculosis," Clin Infect Dis, 50 (2010), S156S64.

6. R. Vázquez-Gallardo, L. Anibarro, A. Fernández-Villar, D. DíazCabanela, E. Cruz-Ferro, M.L. Pérez del Molino, V. Túñez, S. Samper and M.J. Iglesias, "Multidrug-resistant tuberculosis in a low-incidence region shows a high rate of transmission," Int J Tuberc Lung Dis, 11 (2007), 429-35.

7. G.E. Velásquez, M. Yagui, J.P. Cegielski, L. Asencios, J. Bayona, C. Bonilla, H.O. Jave, G. Yale, C. Suárez, S. Atwood, C.C. Contreras and S.S. Shin, "Targeted drug-resistance testing strategy for multidrugresistant tuberculosis detection, Lima, Peru, 2005-2008," Emerg Infect Dis, 17 (2011), 432-40.

8. V. Vella, V. Racalbuto, R. Guerra, C. Marra, A. Moll, Z. Mhlanga, M. Maluleke, H. Mhlope, B. Margot, G. Friedland, N.S. Shah and N.R. Gandhi, "Household contact investigation of multidrug-resistant and extensively drug-resistant tuberculosis in a high HIV prevalence setting," Int J Tuberc Lung Dis, 15 (2011), 1170-75.

9. T.C. Victor, A.M. Jordaan, A. van Rie, G.D. van der Spuy, M. Richardson, P.D. van Helden and R. Warren, "Detection of mutations in drug resistance genes of Mycobacterium tuberculosis by a dot-blot hybridization strategy," Tubercle and Lung Disease, 79 (1999), 34348.

10. X. Wang, Q. Fu, Z. Li, S. Chen, Z. Liu, H. Nelson, Q. Yang, Z. Jia and C. Dye, "Drug-Resistant Tuberculosis in Zhejiang Province, China, 1999-2008," Emerg Infect Dis, 18 (2012), 496-98.

11. J.R. Andrews, N.S. Shah, D. Weissman, A.P. Moll, G. Friedland and N.R. Gandhi, "Predictors of Multidrug- and Extensively Drug- 
Resistant Tuberculosis in a High HIV Prevalence Community," PLoS ONE, 5 (2010), e15735.

12. M.C. Becerra, S.C. Appleton, M.F. Franke, K. Chalco, F. Arteaga, J. Bayona, M. Murray, S.S. Atwood and C.D. Mitnick, "Tuberculosis burden in households of patients with multidrug-resistant and extensively drug-resistant tuberculosis: a retrospective cohort study," Lancet., 377 (2011), 147-52.

13. M. Berry and O.M. Kon, "Multidrug- and extensively drug-resistant tuberculosis: an emerging threat," European Respiratory Review, 18 (2009), 195-97.

14. N.R. Gandhi, P. Nunn, K. Dheda, H.S. Schaaf, M. Zignol, D. van Soolingen, P. Jensen and J. Bayona, "Multidrug-resistant and extensively drug-resistant tuberculosis: a threat to global control of tuberculosis," The Lancet, 375 (2010), 1830-43.

15. L. Grandjean and D.A.J. Moore, "Tuberculosis in the developing world: recent advances in diagnosis with special consideration of extensively drug-resistant tuberculosis (XDR-TB)," Curr Opin Infect Dis, 21 (2008), 454-61.

16. S.K. Heysell, A.P. Moll, N.R. Gandhi, F.J. Eksteen, P. Babaria, Y. Coovadia, L. Roux, U. Lalloo, G. Friedland and N.S. Shah, "Extensively Drug-Resistant Mycobacterium tuberculosis from Aspirates, Rural South Africa," Emerg Infect Dis, 16 (2010), 557-60.

17. T.A. Thomas, S.V. Shenoi, S.K. Heysell, F.J. Eksteen, V.B. Sunkari, N.R. Gandhi, G. Friedland and N.S. Shah, "Extensively drug-resistant tuberculosis in children with human immunodeficiency virus in rural South Africa," Int J Tuberc Lung Dis, 14 (2010), 1244-51.

18. S. Tiberi, E. Petersen, M. Maeurer, F. Ntoumi, D. Yeboa-Manu, P. Mwaba, C. Vilaplana, O. Dar, M. Bates, T. Corrah, M. Rao, N. Kapata, E.I. Azhar, Z.A. Memish, S. Mfinanga, A. Aseffa, G. Ippolito, G.B. Migliori and A. Zumla, "Taking forward the Stop TB Partnership and World Health Organization Joint Theme for World TB Day March 24th 2018 - "Wanted: Leaders for a TB-Free World. You can make history. End TB"," Int J Infect Dis, 68 (2018), 122-24.

19. R. Tschopp, K. Bobosha, A. Aseffa, E. Schelling, M. Habtamu, R. Iwnetu, E. Hailu, R. Firdessa, J. Hussein, D. Young and J. Zinsstag, "Bovine tuberculosis at a cattle-small ruminant-human interface in Meskan, Gurage region, Central Ethiopia," BMC Infectious Diseases, 11 (2011), 318

20. M.A. Miller, P. Buss, E.O. Roos, G. Hausler, A. Dippenaar, E. Mitchell, L. van Schalkwyk, S. Robbe-Austerman, W.R. Waters, A. Sikar-Gang, K.P. Lyashchenko, S.D.C. Parsons, R. Warren and P. van Helden, "Fatal Tuberculosis in a Free-Ranging African Elephant and One Health Implications of Human Pathogens in Wildlife," Front Vet Sci. , 6 (2019), 18-18.

21. N.H. Smith, S. Berg, J. Dale, A. Allen, S. Rodriguez, B. Romero, F. Matos, S. Ghebremichael, C. Karoui, C. Donati, A.d.C. Machado, C. Mucavele, R.R. Kazwala, M. Hilty, S. Cadmus, B.N.R. Ngandolo, M. Habtamu, J. Oloya, A.l. Muller, F. Milian-Suazo, O. Andrievskaia, M. Projahn, S. Barandiarán, A. Macías, B. Müller, M.S. Zanini, C.Y. Ikuta, C.A.R. Rodriguez, S.R. Pinheiro, A. Figueroa, S.-N. Cho, N. Mosavari, P.-C. Chuang, R. Jou, J. Zinsstag, D. van Soolingen, E. Costello, A. Aseffa, F. Proaño-Perez, F.o. Portaels, L. Rigouts, A.A. Cataldi, D.M. Collins, M.L. Boschiroli, R.G. Hewinson, J.S.F. Neto, O. Surujballi, K. Tadyon, A. Botelho, A.M. Zárraga, N. Buller, R. Skuce, A. Michel, A. Aranaz, S.V. Gordon, B.-Y. Jeon, G. Källenius, S. Niemann, M.B. Boniotti, P.D. van Helden, B. Harris, M.J. Zumárraga and K. Kremer, "European 1: A globally important clonal complex of Mycobacterium bovis," Infection, Genetics and Evolution, 11 (2011), 1340-51

22. T.R. Frieden, "Can tuberculosis be controlled?," International Journal of Epidemiology, 31 (2002), 894-99.

23. WHO, "Zoonotic tuberculosis (Mycobacterium bovis): memorandum from a WHO meeting (with the participation of FAO)," Bull World Health Organ, 72 (1994), 851-57.

24. A.J.K. Conlan, T.J. McKinley, K. Karolemeas, E.B. Pollock, A.V. Goodchild, A.P. Mitchell, C.P.D. Birch, R.S. Clifton-Hadley and J.L.N. Wood, "Estimating the hidden burden of bovine tuberculosis in Great Britain," PLoS computational biology, 8 (2012), e1002730-e30

25. E.V. Mbugi, K.A. Kayunze, B.Z. Katale, S. Kendall, L. Good, G.S. Kibik, J.D. Keyyu, P. Godfrey-Faussett, P. van Helden and M.I
Matee, "'One Health' infectious diseases surveillance in Tanzania: Are we all on board the same flight?," Onderstepoort Journal of Veterinary Research, 79 (2012), 01-07.

26. B. Picard, "Molecular epidemiology of large bacterial endemics in Sub-Saharan Africa," Bull Soc Pathol Exot, 93 (2000), 219-23.

27. S. Ghebremichael, R. Petersson, T. Koivula, A. Pennhag, V. Romanus, I. Berggren, B. Petrini, S. Hoffner and G. Källenius, "Molecular epidemiology of drug-resistant tuberculosis in Sweden," Microbes Infect, 10 (2008), 699-705.

28. F. Neely, H. Maguire, F. Le Brun, A. Davies, D. Gelb and S. Yates, "High rate of transmission among contacts in large London outbreak of isoniazid mono-resistant tuberculosis," J Public Health, 32 (2010), $44-51$

29. A. Roetzer, R. Diel, T.A. Kohl, C. Rückert, U. Nübel, J. Blom, T. Wirth, S. Jaenicke, S. Schuback, S. Rüsch-Gerdes, P. Supply, J. Kalinowski and S. Niemann, "Whole Genome Sequencing versus Traditional Genotyping for Investigation of a Mycobacterium tuberculosis Outbreak: A Longitudinal Molecular Epidemiological Study," PLoS Med, 10 (2013), e1001387.

30. V.N. Chihota, A. Niehaus, E.M. Streicher, X. Wang, S.L. Sampson, P. Mason, G. Källenius, S.G. Mfinanga, M. Pillay, M. Klopper, W. Kasongo, M.A. Behr, N.C. Gey van Pittius, P.D. van Helden, D. Couvin, N. Rastogi and R.M. Warren, "Geospatial distribution of Mycobacterium tuberculosis genotypes in Africa," PLOS ONE, 13 (2018), $\mathrm{e} 0200632$.

31. I. Comas, S. Borrell, A. Roetzer, G. Rose, B. Malla, M. Kato-Maeda, J. Galagan, S. Niemann and S. Gagneux, "Whole-genome sequencing of rifampicin-resistant $M$. tuberculosis strains identifies compensatory mutations in RNA polymerase," Nat Genet, 44 (2011), 106-10.

32. X. Yuan, T. Zhang, K. Kawakami, J. Zhu, H. Li, J. Lei and S. Tu, "Molecular Characterization of Multidrug- and Extensively DrugResistant Mycobacterium tuberculosis Strains in Jiangxi, China," $J$ Clin Microbiol, 50 (2012), 2404-13.

33. B.Z. Katale, E.V. Mbugi, L. Botha, J.D. Keyyu, S. Kendall, H.M. Dockrell, A.L. Michel, R.R. Kazwala, M.M. Rweyemamu, P. van Helden and M.I. Matee, "Species diversity of non-tuberculous mycobacteria isolated from humans, livestock and wildlife in the Serengeti ecosystem, Tanzania," BMC Infect Dis, 14 (2014), 1-8.

34. B.R. Kidenya, L.E. Webster, S. Behan, R. Kabangila, R.N. Peck, S.E. Mshana, O. Ocheretina and D.W. Fitzgerald, "Epidemiology and genetic diversity of multidrug-resistant tuberculosis in East Africa," Tuberculosis, 94 (2014), 1-7.

35. N.P. Mnyambwa, D.-J. Kim, E. Ngadaya, J. Chun, S.-m. Ha, P. Petrucka, K.K. Addo, R.R. Kazwala and S.G. Mfinanga, "Genome sequence of Mycobacterium yongonense RT 955-2015 isolate from a patient misdiagnosed with multidrug-resistant tuberculosis: First clinical detection in Tanzania," International Journal of Infectious Diseases, 71 (2018), 82-88.

36. S.G. Mpagama, E.R. Houpt, S. Stroup, H. Kumburu, J. Gratz, G.S. Kibiki and S.K. Heysell, "Application of quantitative second-line drug susceptibility testing at a multidrug-resistant tuberculosis hospital in Tanzania," BMC infectious diseases, 13 (2013), 432-32.

37. S. Berg, M.C. Garcia-Pelayo, B. Muller, E. Hailu, B. Asiimwe, K. Kremer, J. Dale, M.B. Boniotti, S. Rodriguez, M. Hilty, L. Rigouts, R. Firdessa, A. Machado, C. Mucavele, B.N.R. Ngandolo, J. Bruchfeld, L. Boschiroli, A. Muller, N. Sahraoui, M. Pacciarini, S. Cadmus, M. Joloba, D. van Soolingen, A.L. Michel, B. Djonne, A. Aranaz, J. Zinsstag, P. van Helden, F. Portaels, R. Kazwala, G. Kallenius, R.G. Hewinson, A. Aseffa, S.V. Gordon and N.H. Smith, "African 2, a Clonal Complex of Mycobacterium bovis Epidemiologically Important in East Africa," J Bacteriol, 193 (2011), 670-78.

38. L. Durnez, H. Sadiki, A. Katakweba, R. Machang'u, R. Kazwala, H. Leirs and F. Portaels, "The prevalence of Mycobacterium bovisinfection and atypical mycobacterioses in cattle in and around Morogoro, Tanzania " Trop Anim Health Prod, 41 (2009), 1653-59.

39. B.Z. Katale, E.V. Mbugi, K.K. Siame, J.D. Keyyu, S. Kendall, R.R. Kazwala, H.M. Dockrell, R.D. Fyumagwa, A.L. Michel, M. Rweyemamu, E.M. Streicher, R.M. Warren, P. van Helden and M.I. Matee, "Isolation and Potential for Transmission of Mycobacterium bovis at Human-livestock-wildlife Interface of the Serengeti 
Ecosystem, Northern Tanzania," Transbound Emerg Dis, (2015), doi: 10.1111/tbed.12445.

40. R.R. Kazwala, L.J. Kusiluka, K. Sinclair, J.M. Sharp and C.J. Daborn, "The molecular epidemiology of Mycobacterium bovis infections in Tanzania," Vet Microbiol, 112 (2006), 201-10.

41. R.S. Mwakapuja, Z.E. Makondo, J. Malakalinga, I. Moser, R.R. Kazwala and M. Tanner, "Molecular characterization of Mycobacterium bovis isolates from pastoral livestock at MikumiSelous ecosystem in the eastern Tanzania," Tuberculosis, 93 (2013), 668-74.

42. L. Durnez, A. Katakweba, H. Sadiki, C.R. Katholi, R.R. Kazwala, R.R. Machang'u, F. Portaels and H. Leirs, "Mycobacteria in Terrestrial Small Mammals on Cattle Farms in Tanzania," Vet Med International, 2011 (2011), 1-12.

43. V. Eldholm, M. Matee, S. Mfinanga, M. Heun and U. Dahle, "A first insight into the genetic diversity of Mycobacterium tuberculosis in Dar es Salaam, Tanzania, assessed by spoligotyping," $B M C$ microbiology, 6 (2006), 76.

44. A.S. Hoza, S.G. Mfinanga, I. Moser and B. König, "Molecular characterization of Mycobacterium tuberculosis isolates from Tanga, Tanzania: First insight of MIRU-VNTR and microarray-based spoligotyping in a high burden country," Tuberculosis, 98 (2016), $116-24$

45. A.S. Hoza, S.G.M. Mfinanga, A.C. Rodloff, I. Moser and B. König, "Increased isolation of nontuberculous mycobacteria among TB suspects in Northeastern, Tanzania: public health and diagnostic implications for control programmes," BMC Res Notes, 9 (2016), 109.

46. G. Kibiki, B. Mulder, W. Dolmans, J. de Beer, M. Boeree, N. Sam, D. van Soolingen, C. Sola and A. van der Zanden, "M. tuberculosis genotypic diversity and drug susceptibility pattern in HIV- infected and non-HIV-infected patients in northern Tanzania," $B M C$ microbiology, 7 (2007), 51.

47. B.R. Kidenya, S.E. Mshana, D.W. Fitzgerald and O. Ocheretina, "Genotypic drug resistance using whole-genome sequencing of Mycobacterium tuberculosis clinical isolates from North-western Tanzania," Tuberculosis, 109 (2018), 97-101.

48. E.V. Mbugi, B.Z. Katale, K.K. Siame, J.D. Keyyu, S.L. Kendall, H.M Dockrell, E.M. Streicher, A.L. Michel, M.M. Rweyemamu, R.M. Warren, M.I. Matee and P.D. van Helden, "Genetic diversity of Mycobacterium tuberculosis isolated from tuberculosis patients in the Serengeti ecosystem in Tanzania," Tuberculosis, 95 (2015), 170-78.

49. E.V. Mbugi, B.Z. Katale, E.M. Streicher, J.D. Keyyu, S.L. Kendall, H.M. Dockrell, A.L. Michel, M.M. Rweyemamu, R.M. Warren, M.I Matee, P.D. van Helden, D. Couvin and N. Rastogi, "Mapping of Mycobacterium tuberculosis Complex Genetic Diversity Profiles in Tanzania and Other African Countries," PLOS ONE, 11 (2016), e0154571.

50. B.R. Kidenya, S.E. Mshana, L. Gerwing-Adima, J. Kidola and C. Kasang, "Drug adherence and efficacy of smear microscopy in the diagnosis of pulmonary tuberculosis after 2 months of medication in North-western Tanzania," International Journal of Infectious Diseases, 63 (2017), 43-47.

51. J. Bazira, B. Asiimwe, M. Joloba, F. Bwanga and M. Matee, "Mycobacterium tuberculosis spoligotypes and drug susceptibility pattern of isolates from tuberculosis patients in South-Western Uganda," BMC Infectious Diseases, 11 (2011), 81.

52. J. Bazira, M. Matte, B.B. Asiimwe and L.M. Joloba, "Genetic diversity of Mycobacterium tuberculosis in Mbarara, South Western Uganda," African Health Sciences, 10 (2010), 306-11.

53. B. Asiimwe, S. Ghebremichael, G. Kallenius, T. Koivula and M. Joloba, "Mycobacterium tuberculosis spoligotypes and drug susceptibility pattern of isolates from tuberculosis patients in periurban Kampala, Uganda," BMC Infectious Diseases, 8 (2008), 101.

54. B.B. Asiimwe, T. Koivula, G. Källenius, R.C. Huard, S. Ghebremichael, J. Asiimwe and M.L. Joloba, "Mycobacterium tuberculosis Uganda genotype is the predominant cause of TB in Kampala, Uganda," Int J Tuberc Lung Dis, 12 (2008).

55. K. Dickman, L. Nabyonga, D. Kateete, F. Katabazi, B. Asiimwe, H. Mayanja, A. Okwera, C. Whalen and M. Joloba, "Detection of multiple strains of Mycobacterium tuberculosis using MIRU-VNTR in patients with pulmonary tuberculosis in Kampala, Uganda," BMC Infectious Diseases, 10 (2010), 349.

56. B.B. Asiimwe, J. Asiimwe, G. Kallenius, F.K. Ashaba, S. Ghebremichael, M. Joloba and T. Koivula, "Molecular characterisation of Mycobacterium bovis isolates from cattle carcases at a city slaughterhouse in Uganda," Vet Rec, 164 (2009), 655-58.

57. C. Lienhardt, K. Lönnroth, D. Menzies, M. Balasegaram, J. Chakaya, F. Cobelens, J. Cohn, C.M. Denkinger, T.G. Evans, G. Källenius, G. Kaplan, A.M.V. Kumar, L. Matthiessen, C.S. Mgone, V. Mizrahi, Y.d. Mukadi, V.N. Nguyen, Nordström, Anders, C.F. Sizemore, M. Spigelman, S.B. Squire, S. Swaminathan, P.D. Van Helden, A. Zumla, K. Weyer, D. Weil and M. Raviglione, "Translational Research for Tuberculosis Elimination: Priorities, Challenges, and Actions," PLOS Medicine, 13 (2016), e1001965.

58. R.R. Kazwala, D.M. Kambarage, C.J. Daborn, J. Nyange, S.F.H. Jiwa and J.M. Sharp, "Risk Factors Associated with the Occurrence of Bovine Tuberculosis in Cattle in the Southern Highlands of Tanzania," Vet Rec Commun, 25 (2001), 609-14.

59. R.R. Kazwala, C.J. Daborn, J.M. Sharp, D.M. Kambarage, S.F.H. Jiwa and N.A. Mbembati, "Isolation of Mycobacterium bovis from human cases of cervical adenitis in Tanzania: a cause for concern?," Int J Tuberc Lung Dis, 5 (2001), 87-91.

60. S. Cleaveland, M.K. Laurenson and L.H. Taylor, "Diseases of humans and their domestic mammals: pathogen characteristics, host range and the risk of emergence," Philosophical Transactions of the Royal Society of London. Series B: Biological Sciences, 356 (2001), 991-99.

61. S.G. Mfinanga, O. Mørkve, R.R. Kazwala, S. Cleaveland, J.M. Sharp, G.M. Shirima and R. Nilsen, "The role of livestock keeping in tuberculosis trends in Arusha, Tanzania," Int J Tuberc Lung Dis, 7 (2003), 695-704.

62. S.G. Mfinanga, O. Mørkve, R.R. Kazwala, S. Cleaveland, J.M. Sharp, G. Shirima and R. Nilsen, "Tribal differences in perception of tuberculosis: a possible role in tuberculosis control in Arusha, Tanzania," Int J Tuberc Lung Dis, 7 (2003), 933-41.

63. G.M. Shirima, R.R. Kazwala and D.M. Kambarage, "Prevalence of bovine tuberculosis in cattle in different farming systems in the eastern zone of Tanzania," Prev Vet Med, 57 (2003), 167-72.

64. S.G. Mfinanga, O. Morkve and R.R.e.a. Kazwala, "Mycobacterial adenitis: role of Mycobacterium bovis, non-tuberculous mycobacteria, HIV infection, and risk factors in Arusha, Tanzania," East Afr Med J 81 (2004), 171-78.

65. S. Cleaveland, T. Mlengeya, R.R. Kazwala, A. Michel, M.T. Kaare, S.L. Jones, E. Eblate, G.M. Shirima and C. Packer, "Tuberculosis in Tanzanian Wildlife," Journal of Wildlife Diseases, 41 (2005), 446-53.

66. C. Søborg, A.B. Andersen, N. Range, W. Malenganisho, H. Friis, P. Magnussen, M.M. Temu, J. Changalucha, H.O. Madsen and P. Garred, "Influence of candidate susceptibility genes on tuberculosis in a high endemic region," Mol Immunol, 44 (2007), 2213-20.

67. B.J. Ngowi, S.G. Mfinanga, J.N. Bruun and O. Morkve, "Pulmonary tuberculosis among people living with HIV/AIDS attending care and treatment in rural northern Tanzania," BMC Public Health 8(2008), 341

68. K. John, R. Kazwala and G. Mfinanga, "Knowledge of causes, clinical features and diagnosis of common zoonoses among medical practitioners in Tanzania," BMC Infect Dis, 8 (2008), 162.

69. J.A.K. Mazet, D.L. Clifford, P.B. Coppolillo, A.B. Deolalikar, J.D. Erickson and R.R. Kazwala, "A "One Health" Approach to Address Emerging Zoonoses: The HALI Project in Tanzania," PLoS Med, 6 (2009), e 1000190.

70. B.J. Weetjens, G.F. Mgode, R.S. Machang'u, R. Kazwala, G. Mfinanga, F. Lwilla, C. Cox, M. Jubitana, H. Kanyagha, R. Mtandu, A. Kahwa, J. Mwessongo, G. Makingi, S. Mfaume, J. Van Steenberge, N.W. Beyene, M. Billet and R. Verhagen, "African pouched rats for the detection of pulmonary tuberculosis in sputum samples," Int $J$ Tuberc and Lung Dis, 13 (2009), 737-43.

71. A. Poling, B.J. Weetjens, C. Cox, G. Mgode, M. Jubitana, R. Kazwala, G.S. Mfinanga and D. Huis in 't Veld, "Using Giant African Pouched Rats to Detect Tuberculosis in Human Sputum Samples: 2009 Findings," Am J Trop Med Hyg 83 (2010), 1308-10. 
72. A. Gamell, A.J. Ntamatungiro, M. Battegay and E. Letang, "Disseminated tuberculosis in an HIV-infected child: rifampicin resistance detected by GeneXpert in a lymph node aspirate but not in cerebrospinal fluid," BMJ case reports, 2015 (2015).

73. G. Sikalengo, A. Ramirez, D. Faini, K. Mwamelo, M. Battegay, L. Jugheli, C. Hatz, K. Reither and E. Letang, "Tuberculous spondylitis diagnosed through Xpert MTB/RIF assay in urine: a case report," BMC infectious diseases, 16 (2016), 514-14.

74. M. Sariko, C. Anderson, B.S. Mujaga, J. Gratz, S.G. Mpagama, S. Heysell, G. Kibiki, B. Mmbaga, E. Houpt and T. Thomas, "Evaluation of the Antibody in Lymphocyte Supernatant Assay to Detect Active Tuberculosis," PLOS ONE, 12 (2017), e0169118.

75. N.P. Mnyambwa, E.S. Ngadaya, G. Kimaro, D.-J. Kim, R. Kazwala, P. Petrucka and S.G. Mfinanga, "Assessment of sputum smearpositive but culture-negative results among newly diagnosed pulmonary tuberculosis patients in Tanzania," International journal of general medicine, 10 (2017), 199-205.

76. P.M. Mbelele, S. Aboud, S.G. Mpagama and M.I. Matee, "Improved performance of Xpert MTB/RIF assay on sputum sediment samples obtained from presumptive pulmonary tuberculosis cases at Kibong'oto infectious diseases hospital inÂ Tanzania," $B M C$ infectious diseases, 17 (2017), 808.

77. N.P. Mnyambwa, I. Lekule, E.S. Ngadaya, G. Kimaro, P. Petrucka, D.-J. Kim, J. Lymo, R. Kazwala, F. Mosha and S.G. Mfinanga, "Assessment of GeneXpert GxAlert platform for multi-drug resistant tuberculosis diagnosis and patients' linkage to care in Tanzania," BMC research notes, 11 (2018), 121-21.

78. M. Beyanga, B.R. Kidenya, L. Gerwing-Adima, E. Ochodo, S.E. Mshana and C. Kasang, "Investigation of household contacts of pulmonary tuberculosis patients increases case detection in Mwanza City, Tanzania," BMC infectious diseases, 18 (2018), 110.

79. M.D. Jørstad, M. Marijani, A.M. Dyrhol-Riise, L. Sviland and T. Mustafa, "MPT64 antigen detection test improves routine diagnosis of extrapulmonary tuberculosis in a low-resource setting: A study from the tertiary care hospital in Zanzibar," PLOS ONE, 13 (Jørstad), e0196723.

80. J.R. Glynn, "Resurgence of tuberculosis and the impact of HIV infection," Br Med Bull, 54 (1998), 579-93.

81. K.H. Mayer and C.D. Hamilton, "Synergistic Pandemics: Confronting the Global HIV and Tuberculosis Epidemics," Clinical Infectious Diseases, 50 (2010), S67-S70.

82. A. Pawlowski, M. Jansson, M. SkÃ đld, M.E. Rottenberg and G. KÃallenius, "Tuberculosis and HIV co-infection," PLoS pathogens, 8 (2012), e1002464-e64.

83. S. Suchindran, E.S. Brouwer and A. Van Rie, "Is HIV Infection a Risk Factor for Multi-Drug Resistant Tuberculosis? A Systematic Review," PLOS ONE, 4 (2009), e5561.

84. K.R. Jacobson, M. Barnard, M.B. Kleinman, E.M. Streicher, E.J. Ragan, L.F. White, O. Shapira, T. Dolby, J. Simpson, L. Scott, W. Stevens, P.D. van Helden, A. Van Rie and R.M. Warren, "Implications of Failure to Routinely Diagnose Resistance to Second-Line Drugs in Patients With Rifampicin-Resistant Tuberculosis on Xpert MTB/RIF: A Multisite Observational Study," Clin Iinfect Dis, 64 (2017), 150208.

85. M. Klopper, R.M. Warren, C. Hayes, N.C. Gey van Pittius, E.M Streicher, B. MÃ̃1/4ller, F.A. Sirgel, M. Chabula-Nxiweni, E. Hoosain, G. Coetzee, P. David van Helden, T.C. Victor and A.P. Trollip, "Emergence and spread of extensively and totally drug-resistant tuberculosis, South Africa," Emerging infectious diseases, 19 (2013), 449-55.

86. B. Müller, V.N. Chihota, M. Pillay, M. Klopper, E.M. Streicher, G. Coetzee, A. Trollip, C. Hayes, M.E. Bosman, N.C. Gey van Pittius, T.C. Victor, S. Gagneux, P.D. van Helden and R.M. Warren, "Programmatically selected multidrug-resistant strains drive the emergence of extensively drug-resistant tuberculosis in South Africa," PLOS ONE, 8 (2013), e70919-e19.

87. E.M. Streicher, I. Bergval, K. Dheda, E.C. Böttger, N.C.G.V. Pittius, M. Bosman, G. Coetzee, R.M. Anthony, P.D.V. Helden, T.C. Victor and R.M. Warren, "Mycobacterium tuberculosis population structure determines the outcome of genetics-based second-line drug resistance testing," Antimicrobial Agents and Chemotherapy, 56 (2012), 242027.

88. E.M. Streicher, B. Müller, V. Chihota, C. Mlambo, M. Tait, M. Pillay, A. Trollip, K.G.P. Hoek, F.A. Sirgel, N.C.G. van Pittius, P.D.v. Helden, T.C. Victor and R.M. Warren, "Emergence and treatment of multidrug resistant (MDR) and extensively drug-resistant (XDR) tuberculosis in South Africa," Infection, Genetics and Evolution, 12 (2012), 686-94

89. R.M. Warren, Hoek K, Sirgel F, Tait M, Gey van Pittius NC, Müller B, Streicher EM, Victor TC and V.H. PD., "Emergence and treatment of drug resistant tuberculosis: A comedy of errors," S Afr Res J, 16 (2011), 112-16.

90. T.D. Ogaro, W. Githui, G. Kikuvi, J. Okari, V. Asiko, E. Wangui, A.M. Jordaan, P.D. Van Helden, M.E. Streicher and T.C. Victor, "Diversity of Mycobacterium tuberculosis strains in Nairobi, Kenya," Afr J Health Sci, 20 (2012), 82-90.

91. F. Koro Koro, Y. Kamdem Simo, F.1.F. Piam, J. Noeske, C. Gutierrez, C. Kuaban and S.I.n. Eyangoh, "Population Dynamics of Tuberculous Bacilli in Cameroon as Assessed by Spoligotyping," Journal of Clinical Microbiology, 51 (2013), 299-302.

92. S. Arega, F. Conraths and G. Ameni, "Prevalence of tuberculosis in pigs slaughtered at two abattoirs in Ethiopia and molecular characterization of Mycobacterium tuberculosis isolated from tuberculous-like lesions in pigs," BMC Vet Res, 9 (2013), 97.

93. B. Muller, M. Hilty, S. Berg, M.C. Garcia-Pelayo, J. Dale, M.L. Boschiroli, S. Cadmus, B.N.R. Ngandolo, S. Godreuil, C. Diguimbaye-Djaibe, R. Kazwala, B. Bonfoh, B.M. NjanpopLafourcade, N. Sahraoui, D. Guetarni, A. Aseffa, M.H. Mekonnen, V.R. Razanamparany, H. Ramarokoto, B. Djonne, J. Oloya, A. Machado, C. Mucavele, E. Skjerve, F. Portaels, L. Rigouts, A. Michel, A. Muller, G. Kallenius, P.D. van Helden, R.G. Hewinson, J. Zinsstag, S.V. Gordon and N.H. Smith, "African 1, an Epidemiologically Important Clonal Complex of Mycobacterium bovis Dominant in Mali, Nigeria, Cameroon, and Chad," J. Bacteriol., 191 (2009), 195160.

94. S. Rodriguez-Campos, A.C. Schürch, J. Dale, A.J. Lohan, M.V. Cunha, A. Botelho, K.D. Cruz, M.L. Boschiroli, M.B. Boniotti, M. Pacciarini, M.C. Garcia-Pelayo, B. Romero, L. de Juan, L. Domínguez, S.V. Gordon, D. van Soolingen, B. Loftus, S. Berg, R.G. Hewinson, A. Aranaz and N.H. Smith, "European 2 - A clonal complex of Mycobacterium bovis dominant in the Iberian Peninsula," Infect Genet Evol, 12 (2012), 866-72.

95. A. Dippenaar, S.D.C. Parsons, M.A. Miller, T. Hlokwe, N.C. Gey van Pittius, S.A. Adroub, A.M. Abdallah, A. Pain, R.M. Warren, A.L. Michel and P.D. van Helden, "Progenitor strain introduction of Mycobacterium bovis at the wildlife-livestock interface can lead to clonal expansion of the disease in a single ecosystem," Infection, Genetics and Evolution, 51 (2017), 235-38.

96. R.W. Brooks, K.L. George, B.C. Parker, J.O. Falkinham and H. Gruff, "Recovery and survival nontuberculous mycobacteria under various growth and decontamination conditions," Can J Microbiol, 30 (1984), 1112-17.

97. A.R.F. da Costa, J.O. Falkinham, M.L. Lopes, A.R. Barretto, J.S. Felicio, L.H.M. Sales, J.R.d.C. Bahia, E.C. Conceicao and K.V.B. Lima, "Occurrence of Nontuberculous Mycobacterial Pulmonary Infection in an Endemic Area of Tuberculosis," PLoS Negl Trop Dis, 7 (2013), e2340.

98. M. Hatherill, T. Hawkridge, A. Whitelaw, M. Tameris, H. Mahomed, S. Moyo, W. Hanekom and G. Hussey, "Isolation of Non-Tuberculous Mycobacteria in Children Investigated for Pulmonary Tuberculosis," PLoS ONE, 1 (2006), e21.

99. T.P. Primm, C.A. Lucero and J.O. Falkinham, "Health impacts of environmental mycobacteria," Clin Microbiol Rev, 17 (2004), 98-106.

100. B. Asiimwe, G. Bagyenzi, W. Ssengooba, F. Mumbowa, G. Mboowa, A. Wajja, H. Mayanja-Kiiza, P. Musoke, E. Wobudeya, G. Kallenius and M. Joloba, "Species and genotypic diversity of non-tuberculous mycobacteria isolated from children investigated for pulmonary tuberculosis in rural Uganda," BMC Infect Dis, 13 (2013), 88. 
101. L. Botha, N.C. Gey van Pittius and P.D. van Helden, "Mycobacteria and Disease in Southern Africa," Transboundary and Emerging Diseases, 60 (2013), 147-56.

102. M.H. Haverkamp, S.M. Arend, J.A. Lindeboom, N.G. Hartwig and J.T. van Dissel, "Nontuberculous Mycobacterial Infection in Children: A 2-Year Prospective Surveillance Study in The Netherlands," Clinical Infectious Diseases, 39 (2004), 450-56.

103. P. Buijtels, Clinical relevance of non-tuberculous mycobacteria in Zambia In Department of Medical Microbiology, (Rotterdam: Medical Centre Rijnmond-Zuid, The Netherlands, 2007), 220.

104. C.D. Robson, R. Hazra, P.D. Barnes, R.L. Robertson, D. Jones and R.N. Husson, "Nontuberculous Mycobacterial Infection of the Head and Neck in Immunocompetent Children: CT and MR Findings," American Journal of Neuroradiology, 20 (1999), 1829-35.

105. T.C. Covert, M.R. Rodgers, A.L. Reyes and G.N. Stelma, Jr., "Occurrence of nontuberculous mycobacteria in environmental samples," Applied and environmental microbiology, 65 (1999), 2492-

106. G. Meissner and W. Anz, "Sources of Mycobacterium avium complex infection resulting in human diseases," Am Rev Respir Dis, 116 (1977), 1057-64

107. D.K. Radhakrishnan, Y. Yau, M. Corey, S. Richardson, P. Chedore, F. Jamieson and S.D. Dell, "Non-tuberculous mycobacteria in children with cystic fibrosis: Isolation, prevalence, and predictors," Pediatric Pulmonology, 44 (2009), 1100-06.

108. N. Gcebe, V. Rutten, N.C. Gey van Pittius and A. Michel, "Prevalence and Distribution of Non-Tuberculous Mycobacteria (NTM) in Cattle,
African Buffaloes (Syncerus caffer) and their Environments in South Africa," Transbound Emerg Dis, 60 (2013), 74-84

109. F. Abuzeid, "Foreign Aid and the "Big Push" Theory: Lessons from Sub-Saharan Africa," Stanford Journal of International Relations, XI (2009), 16-23.

\section{Peer Reviewed}

Competing Interests: None declared.

Received: 11 Aug 2019; Accepted: 10 Apr 2020.

Cite this article as: Mbugi EV, Katale B, Keyyu J, Kendall S, Michel AL, Dockrell HM, Rweyemamu M, Helden PDV, Matee M. Tracking characterization of Mycobacterium strains in Tanzania and some subSaharan African Countries: An overview on genotyping studies, implication and trends in advancing technology. E Afr Sci. 2020;1(2):9-21. http://doi.org/10.24248/EASci-D-19-00016

(c) Mbugi et al. This is an open-access article distributed under the terms of the Creative Commons Attribution License, which permits unrestricteduse, distribution, and reproduction in any medium, provided the original author and source are proper-ly cited. To view a copy of the license, visit http://creativecommons.org/licens- es/by/4.0/. When linking to this article, please use the following permanent link: http://doi.org/10.24248/EASci-D-19-00016 